\title{
IMPLEMENTASI PROGRAM ADIWIYATA MANDIRI DALAM PENINGKATAN PARTISIPASI PEMBELAJARAN LINGKUNGAN HIDUP DI SMP NEGERI 12 SURABAYA
}

\author{
Rica Naudita Krisna Setioningrum¹, Jojok Mukono² \\ Fakultas Kesehatan Masyarakat Universitas Airlangga

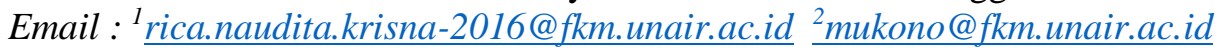

\begin{abstract}
Abstact
This research is located at SMP Negeri 12 Surabaya, which is one of the junior high schools that started pioneering for Adiwiyata schools starting in 2010. The aim of implementing the Adiwiyata program in this school is to create schools that are caring, cultured in the environment and increasing participation in environmental learning. This study has a sub-focus of discussion that has been determined namely the environmentally sound policies that are applied, the implementation of the environment-based curriculum applied, participatory environment-based activities, management of environmentally friendly supporting facilities implemented at SMP Negeri 12 Surabaya. The methodology used is a qualitative method with a descriptive approach. The procedure of collecting research data is observation, in-depth interviews and documentation. Data sources are interviews of adiwiyata team members, team members and teachers. The data analysis of this research used an interactive data analysis model with data collection, data reduction, data presentation and verification. The results of the study showed that the school succeeded in obtaining the Adiwiyata Mandiri school award by forming 15 working groups and establishing 15 activities to support the implementation of the Adiwiyata program. Each working group has a minimum of 2 teachers as supervisors and 12 to 20 students. These activities are in the form of takakura waste processing, composter, toga plants, healthy canteen, a clean Friday,4R (Reuse, Reduce, Recycle, Replace), etc.The program implemented as a strategic program has long-term and sustainable benefit.
\end{abstract}

Keywords: Adiwiyata Program, Participation, and the Environment

\section{PENDAHULUAN}

Pembangunan nasional di bidang pendidikan merupakan salah satu tujuan negara Indonesia yaitu untuk mencerdaskan bangsa dan meningkatkan kualitas sumber daya manusia dalam mewujudkan masyarakat yang maju dan makmur. Salah satu permasalahan dalam pelaksanaan pendidikan lingkungan hidup selama ini yaitu rendahnya partisipasi masyarakat untuk berperan dalam pendidikan lingkungan hidup yang disebabkan oleh kurangnya pemahaman permasalahan pendidikan lingkungan yang
Volume XXI

Nomor 1
Maret 2020

e-ISSN : 2580-9199 
ada , rendahnya tingkat kemampuan atau keterampilan dan rendahnya komitmen masyarakat dalam menyelesaikan masalah tersebut.

Sekolah adalah hal yang paling mempengaruhi sikap dari seorang anak selain dari lingkungan keluarga. Secara umum sekolah merupakan tempat dimana seorang anak distimulasi untuk belajar dibawah pengawasan guru. Sekolah juga merupakan tempat yang cocok bagi siswa dalam perkembangannya dan menjadi sebuah lingkungan sosial yang dapat mempengaruhi kehidupan masa depan anak. Penanaman kepedulian siswa terhadap lingkungan dan sumber daya alam yang ada di bumi perlu dikakukan sejak dini melalui perantara sekolah sehingga terbentuk dalam diri para siswa rasa menghargai, memiliki, dan memelihara sumber daya alam.

Pendidikan mengenai lingkungan hidup di sekolah merupakan salah satu penerapan pendidikan karakater. Pendidikan karakter dan pendidikan lingkungan hidup, menanamkan nilai-nilai karakter siswa. Tidak hanya peran dari siswa saja tetapi warga sekolah sekaligus turut berperan. Hal ini meliputi pengetahuan (kognitif), kesadaran atau kemauan (afektif), dan tindakan (psikomotor) untuk melaksanakan nilainilai tersebut.
Pemahaman tentang menjaga dan melestarikan lingkungan agar tetap terjaga menjadi lingkungan yang seimbang dalam kehidupan di bumi ini perlu dipahami oleh semua masyarakat dan hal ini harus ditanamkan kepada generasi ke generasi. Kesadaran menjaga lingkungan hidup perlu di tanamkan kepada manusia dan perlu dilakukan sejak dini sehingga tertanam nilai-nilai kecintaan akan lingkungan.

Diharapkan dengan pemahaman nilai-nilai kecintaan terhadap lingkungan ini, maka dapat meningkatkan pengetahuan dan pemahaman menjaga kelestarian lingkungan, sehinggga menumbuhkan kesadaran para generasi untuk ikut terlibat dalam menjaga dan melestarikan lingkungan. Keterlibatan pihak sekolah dalam upaya ini maka peran pemerintah sangat penting untuk menjadi pengontrol bagi jalannya program implementasi pemahaman dan pengetahuan tentang lingkungan hidup di sekolah.

Pemahaman lingkungan hidup telah dimasukan dalam salah satu mata pelajaran berdasarkan kesepakatan antara Menteri Negara Lingkungan Hidup dengan Menteri Pendidikan Nasional dalam Keputusan nomor: Kep07/MENLH/06/2005 - Nomor : 05/VI/KB/2005 tentang Pembinaan dan Pengembangan. 
Tujuan utama dari kesepakatan ini adalah agar pembelajaran Pendidikan Lingkungan Hidup (PLH) dapat terintegrasi dalam kurikulum pendidikan nasional sehingga dapat mewujudkan perubahan perilaku peserta didik menjadi ramah lingkungan. Pendidikan Lingkungan Hidup yang diintegrasikan dalam kurikulum pendidikan nasional tentu mempengaruhi perkembangan siswa baik bidang akademis, sosial maupun pribadi.

Pelaksanaan pembelajaran PLH merupakan proses pembelajaran yang menargetkan 3 pencapaian sukses yaitu: (1)Sukses kognitif, siswa memiliki pengetahuan dan pemahaman mngenai permasalahan lingkungan hidup dan kependudukan serta wawasan bumi; (2) sukses afektif yaitu menumbuhkan dalam diri siswa tentang kesadaran, sikap dan perilaku serta membangkitkan keinginan berpartsipasi aktif untuk pemecahan permasalahan lingkungan hidup. Prtisipasi yang diharapakan dapat berupa usaha pencegahan timbulnya masalah maupun usaha penanggulanagan masalah yang timbul dimana usaha tersebut dilakukan oleh para peserta didik PLH; (3) sukses psikomotorik, dimana para peserta didik PLH memiliki keterampilan yang efektif dan aplikatif dalam upaya pencegahan dan penanggulangan masalah lingkungan hidup (Hammado Tantu, 2016). Ketiga target tersebut dalah direalisasikan dengan strategi pembelajaran yang sistematik, komprehensif, dan terpadu dimulai dari tahap perencanaan, tahap implementasi dan tahap evaluasi pembelajaran PLH dengan didukung oleh adanya program sekolah Adiwiyata.

Sekolah Adiwiyata merupakan sekolah yang baik dan ideal untuk memperoleh ilmu pengetahuan dan berbagai norma serta etika yang dapat menjadi dasar manusia menuju kesejahteraan hidup dalam mewujudkan cita-cita pembangunan berkelanjutan (Peraturan Menteri Negara Lingkungan Hidup nomor 02, 2009). Berdasarkan Peraturan Menteri Lingkungan Hidup nomor 5 Tahun 2013 tentang pedoman pelaksanaan program Adiwiyata, yang dimaksud dengan sekolah Adiwiyata adalah sekolah yang peduli dan berbudaya lingkungan.

Salah satu sekolah di Kota Surabaya yang menerapkan program Adiwiyata yait SMP Negeri 12 Surabaya. SMP Negeri 12 Surabaya mulai merintis untuk sekolah adiwiyata mulai tahun 2010. Mulai mendapatkan penghargaan Adiwiyata pada tahun 2014. Pada saat ini SMP Negeri 12 Surabaya telah mendapatkan penghargaan sekolah Adiwiyata Mandiri tingkat nasional dan akan menuju tingkat mandiri pada tahun 
2019. SMP Negeri 12 Surabaya telah memiliki 6 sekolah binaan dimana 4 diantaranya sudah mendapatkan penghargaan tingkat Kabupaten/Kota.

Penelitian ini fokus pada implementasi program Adiwiyata di SMP Negeri 12 Surabaya dengan beberapa subfokus yang telah ditetapkan yaitu: (1) kebijakan berwawasan lingkungan yang diterapkan.(2) Pelaksanaan kurikulum berbasis lingkungan yang diterapkan. (3) Kegiatan lingkungan berbasis partisipatif. (4) Pengelolaan sarana pendukung ramah lingkungan yang diterapkan di SMP Negeri 12 Surabaya.

\section{A. Partisipasi dalam Pendidikan}

\section{Lingkungan Hidup}

Partisipasi adalah keikutsertaan seseorang untuk memberikan sumbangan-sumbangan pada proses pembuatan keputusan. Partisipasi adalah keterlibatan yang bersifat spontan yang disertai tanggung jawab terhadap kepentingan bersama (Laras Sih, 2017)

Sifat dari partisipasi adanya kesadaran dari masing-masing anggota kelompok sehingga anggota memiliki rasa memiliki dan tidak ada unsur paksaan (Suryosubroto, 2009)

Berdasarkan beberapa pengertian di atas, maka dapat disimpulkan bahwa partisipasi adalah keterlibatan siswa baik secara emosional, fisik dan mental untuk memberikan inisiatif dalam menjalankan kegiatan-kegiatan berbasis lingkungan hidup di sekolah. Siswa memiliki tanggung jawab menjaga kelestarian lingkungan karena rasa senasib dalam melaksanakan program sekolah Adiwiyata. Partisipasi siswa dalam pendidikan lingkungan hidup tidak sekedar menerima teori saja melainkan melaksanakan praktik secara langsung sesuai kebijakan yang diterapkan oleh pihak sekolah.

\section{B. Kegiatan Siswa dalam Program Adiwiyata}

Pelaksanaan program Adiwiyata dapat berjalan maksimal jika semua warga sekolah melakukan kerjasama dalam pelaksanaan kegiatan. Program Adiwiyata atau sekolah berbasis lingkungan hidup membagi tugas kepada semua warga sekolah sesuai dengan kemampuan yang dimiliki. Hal tersebut merupakan faktor pendukung pelaksanaan program Adiwiyata di sekolah.

Seperti penjelasan Lusty (2013) bahwa peran guru, siswa, kepala sekolah dan pihak terkait lainnya sangat berdampak terhadap kualitas mutu pendidikan dan lembaga pendidikan.

Tugas pokok siswa dalam melakukan kegiatan program Adiwiyata yaitu:
Volume XXI
Nomor 1
Maret 2020

e-ISSN : 2580-9199 
1) Siswa wajib menghasilkan karya nyata misalnya artikel, daur ulang, makalah dan lainnya.

2) Terlibat dalam pelestarian lingkungan hijau dan mencegah pencemaran lingkungan.

3) Mengkomunikasikan hasil belajar lingkungan hidup melalui berbagai media yang ada.

4) Merawat dan memelihara gedung di sekolah.

5) Siswa memanfaatkan lahan dan fasilitas sekolah ssesuai dengan kaidah pengelolaan lingkungan hijau.

6) Siswa mampu mengembangkan ekstrakurikuler yang sesuai dengan kaidah pelestarian lingkungan hijau.

7) Siswa dapat berkreativitas dalam pengolahan dan daur ulang sampah yang ada.

8) Siswa menggunakan sarana dan prasarana di sekolah yang ramah lingkungan.

9) Memanfaatkan energi listrik, air dan alat tulis secara efisien di lingkungan sekolah.

Pelaksanaan program Adiwiyata diposisikan dalam dua prinsip yaitu prinsip partisipatif yang berarti seluruh komponen di sekolah terlibat dalam keseluruhan proses pelaksanaan, dimulai dari proses perencanaan, proses implementasi dan proses evaluasi. Prinsip yang kedua adalah berkelanjutan (sustainable) dimana seluruh kegiatan yang terencana dilakukan secara terus menerus secara komprehensif (Maryani, 2016)

\section{METODOLOGI}

Metode penelitian ini menggunakan metode kualitatif dengan pendekatan deskriptif. Pendekatan deskriptif kualitataif atau naturalistik dimana peneliti harus memasuki lapangan untuk mengumpulkan data melalui observasi dan wawancara (Rahmat Pupu, 2009).

$$
\text { Penelitian ini fokus pada }
$$
implementasi program Adiwiyata di SMP Negeri 12 Surabaya dengan beberapa subfokus yang telah ditetapkan yaitu: (1) kebijakan berwawasan lingkungan yang diterapkan.(2) Pelaksanaan kurikulum berbasis lingkungan yang diterapkan. (3) Kegiatan lingkungan berbasis partisipatif. (4) Pengelolaan sarana pendukung ramah lingkungan yang diterapkan di SMP Negeri 12 Surabaya.

Lokasi penelitian dilakukan di SMP Negeri 12 Surabaya yang berada di Jalan Ngagel Kebon Sari I Surabaya, Jawa Timur. Prosedur pengumpulan data penelitian yaitu observasi, wawancara mendalam dan dokumentasi. Sumber data yaitu wawancara anggota tim adiwiyata, anggota tim dan guru. Analisis data penelitian ini menggunakan model analisis data interaktif dengan pengumpulan data, 
reduksi data, penyajian data dan verifikasi/ penarikan kesimpulan (B. Matthew Miles, 1992)

\section{HASIL DAN PEMBAHASAN}

1. Kebijakan berwawasan lingkungan yang diterapkan di SMP Negeri 12 Surabaya

a. Kurikulum Tingkat Satuan Pendidikan (KTSP) membuat kebijakan upaya perlindungan dan pengelolaan lingkungan hidup.

Visi SMP Negeri 12 Surabaya :

1) Terwujudnya siswa yang unggul dalam prestasi baik akademik maupun nonakademik sehingga mampu menghadapi perkembangan zaman.

2) Terwujudnya tenaga pendidik dan kependidikan yang unggul dalam mengantarkan siswa mencapai prestasi akademik dan nonakademik.

3) Terwujudnya warga sekolah yang beriman dan bertaqwa terhadap Tuhan Yang Maha Esa

4) Terwujudnya kepribadian warga sekolah yang mantap, handarbeni, berakhlak mulia, dan menjunjung nilai-nilai Pancasila terbentuknya warga sekolah yang berbudaya di bidang lingkungan hidup, sosial, iptek, dan seni serta memiliki wawasan global.

Misi SMP Negeri 12 Surabaya:

Melaksanakan pendidikan dan pengajaran yang bertumpu pada akhlak mulia dalam upaya meningkatkan prestasi akademik dan non akademik dengan mengembangkan budaya sekolah.

Berdasarkan visi pada poin 4 telah menunjukkan sudah memuat kebijakan perlindungan dan pengelolaan linkungan hidup. Berdasarkan Peraturan Menteri Lingkungan Hidup Republik Indonesia Nomor 05 Tahun 2013 tentang pedoman pelaksanaan program Adwiyata, Kurikulum Tingkat Satuan Pendidikan (KTSP) memuat upaya perlindungan dan pengelolaan lingkungan hidup yaitu dengan mengintegrasikan mata pelajaran dengan materi pengelolaan lingkungan hidup.

Pada poin struktur kurikulum memuat mata pelajaran wajib, muatan lokal, pengembangan diri terkait kebijakan perlindungan dan pengelolaan lingkungan hidup serta telah dilakukan dengan adanya pengintegrasian setiap mata pelajarannya. Seperti halnya, jika mengenai mata pelajaran IPA terdapat materi tentang pelestarian mangrove, maka disiapkan dengan adanya kunjungan ke hutan mangrove, membawa contoh tanaman, dan mencari informasi lebih terkait materi yang disampaikan.

Pelaksanaan program Adiwiyata Mandiri di SMA Negeri 12 Surabaya sejalan dengan pendapat Indra P (2018) bahwa pelaksanaan kegiatan dilakukan 
oleh sekolah dengan adanya kegiatan non rutin dan rutin, kegiatan fisik maupun non fisik baik di dalam lingkungan sekolah ataupun di luar sekolah.

b. Rencana Kegiatan dan Anggaran

Sekolah (RKAS) membuat program dalam upaya perlindungan dan pengelolaan lingkungan hidup.

Berdasarkan Permen LH No. 5 tahun 2013 tentang pedoman pelaksanaan program Adwiyata, pada poin rencana kegiatan dan anggaran sekolah memuat upaya perlindungan dan pengelolaan lingkungan hidup, meliputi kesiswaan, kurikulum dan kegiatan pembelajaran, peningkatan kapasitas pendidik dan tenaga kependidikan, tersedianya sarana dan prasarana, budaya dan lingkungan sekolah, peran serta masyarakat dan kemitraan, peningkatan dan pengembangan mutu.

Pada tahun 2019 SMP Negeri 12 Surabaya proses menuju Sekolah Adiwiyata tingkat mandiri, hal ini merupakan sebuah rencana kegiatan dari upaya peningkatan dan pengembangan mutu. Anggaran disini yang dimaksud yaitu perolehan sumber dana SMP Negeri 12 Surabaya. Adapun sumber dana tersebut berasal dari dana BOPDA (Bantuan Operasional Pendidikan Daerah), pemasukan penjualan kertas dan minyak jelantah dan bantuan - bantuan dari mitra kerja SMP Negeri 12 Surabaya baik berupa uang ataupun barang, misalnya pemberian biopori, wastafel, dan lainnya.

Sedangkan pada penelitian lain pelaksanaan RKAS untuk sekolah Adiwiyata Mandiri di Tangerang menganggarkan $20 \%$ dari total anggaran sekolah yang berasal pada sumber dana BOS Pusat ditambah bantuan dana dari pihak luar, dana komite sekolah dan kerjasama mitra untuk digunakan sebagai upaya perlindungan dan pengelolaan lingkungan hidup (Pradini, 2018)

\section{Pelaksanaan kurikulum berbasis} lingkungan yang diterapkan di SMP Negeri 12 Surabaya

Tenaga pendidik memiliki kompetensi dalam mengembangkan kegiatan pembelajaran lingkungan hidup. Berdasarkan Permen LH RI No. 5 tahun 2013 tentang pedoman pelaksanaan program Adwiyata, tenaga pendidik memiliki kompetensi dalam mengembangkan kegiatan pembelajaran lingkungan hidup seperti :

1) Menerapkan pendekatan, strategi, metode, dan teknik pembelajaran yang melibatkan peserta didik secara aktif dalam pembelajaran. Pada poin ini, sekolah telah menerapkannya dengan dibentuknya kader-kader untuk melatih dan mengembangkan potensi siswa-siswi SMP Negeri 12 Surabaya dalam 
mengelola dan menjaga lingkungan. Pada awalnya, kader ini dibentuk oleh tenaga pendidik, namun pada akhirnya banyak siswa-siswi yang juga ikut tertarik dalam menjalankan kegiatan tersebut. Kegiatan tersebut meliputi pengumpulan kertas dan minyak jelantah, pengomposan, 4R (Reuse, Reduce, Recycle, Replace) dan lain-lain.

2) Mengembangkan isu lokal dan/atau isu global sebagai materi pembelajaran lingkungan hidup sesuai dengan jenjang pendidikan. Poin ini sudah diterapkan oleh SMP Negeri 12 Surabaya dengan menerapkan sistem zero waste yaitu mulai dari prosuksi sampai berakhirnya suatu proses produksi dapat dihindari atau meminimalisir terjadinya sampah dengan 4R (reduce, reuse, recycle, replace).

3) Menyusun rancangan pembelajaran yang lengkap, baik untuk kegiatan di dalam kelas, laboratorium, maupun di luar kelas.Poin ini diterapkan dengan adanya kegiatan di dalam kelas yaitu membersihkan ruang kelas sebelum dan selesai kegiatan belajar dan juga di luar kelas seperti kegiatan pengomposan, kegiatan ekstrakurikuler, dan lain - lain.

4) Mengikutsertakan orang tua peserta didik dan masyarakat dalam program pembelajaran lingkungan hidup. Hal ini dibuktikan dengan adanya program dimana setiap anak dianjurkan untuk membawa minyak jelantah dari rumah masing-masing setiap kegiatan Jumat Bersih. Pengumpulan minyak jelantah ini semata - mata agar pembuangan minyak jelantah tersebut tidak sembarangan, dikhawatirkan akan membuang minyak jelantah ini ke saluran pembuangan air yang nantinya dapat mencemari air dan tanah di lingkungan sekitar. Hal ini tentunya melibatkan peran serta orang tua. Siswasiswi SMP Negeri 12 Surabaya juga diwajibkan untuk menanam tanaman, minimal satu tanaman di halaman rumah. Guna mengurangi dampak pemanasan global, menyerap polusi udara, serta sumber oksigen dan lainlain.

5) Mengaitkan pengetahuan konseptual dan prosedural dalam pemecahan masalah lingkungan hidup, serta penerapannya dalam kehidupan seharihari. Poin ini juga telah diterapkan dengan adanya kegiatan seperti : mengurangi penggunaan plastik dengan membawa tumbler/botol minum dari rumah, kegiatan mengumpulkan kertas bekas maupun minyak jelantah yang nantinya akan dikumpulkan dan disetorkan kepada pengepul, dan lainlain.

\section{Volume XXI}

\section{Nomor 1}

Maret 2020

e-ISSN : 2580-9199 
Berdasarkan Permen LH No. 5 tahun 2013 tentang pedoman pelaksanaan program Adwiyata, keterlibatan peserta didik dalam mendukung program sekolah adiwiyata adalah pada poin bahwa peserta didik harus menghasilkan karya nyata yang terkait dengan perlindungan dan pengelolaan lingkungan hidup. Hal ini telah dilakukan oleh peserta didik SMP Negeri 12 Surabaya dalam bentuk membuat kerajinan daur ulang dari sampah kardus, sendok plastik, botol plastik, koran, dan masih banyak lagi yang dipajang di etalase yang telah disediakan oleh sekolah yang dapat ditemukan di lorong gedung U.Selain itu peserta didik juga harus mempunyai kemampuan memecahkan masalah lingkungan hidup dalam kehidupan sehari-hari, hal ini terbukti dari kemampuan para siswa dalam membuat kerajinan daur ulang sampah tersebut sehingga sampah-sampah yang ada di sekitar memiliki nilai guna lain.

Terkait dengan poin peserta didik dapat mengomunikasikan hasil pembelajaran tentang lingkungan hidup yaitu peserta didik selalu didoktrin untuk menerapkan jiwa cinta lingkungan mereka tidak hanya di sekolah namun di lingkungan mana saja seperti di rumah dengan contoh nyata berupa setiap Senin dan Kamis peserta didik diwajibkan membawa minyak bekas pakai dan kertas putih yang sudah digunakan untuk dikumpulkan di sekolah yang nantinya akan disetorkan kepada pengepul. Pengamat melihat hal ini sebagai bukti kemampuan bahwa tiap peserta didik dapat mengomunikasi pembelajaran lingkungan hidup yang didapatkan di sekolah.

Poin selanjutnya mengenai kewajiban warga sekolah untuk terlibat dalam pemeliharaan gedung dan lingkungan sekolah melalui berbagai kegiatan seperti piket kelas, jumat bersih, dan lomba kebersihan kelas juga telah diterapkan di SMP Negeri 12 Surabaya. Pihak sekolah rutin melakukan kegiatan tersebut sehingga pada saat mengamati langsung, kondisi kelas dapat dikatakan bersih dan nyaman untuk beraktivitas. Bahkan terdapat kelas yang mewajibkan penghuninya untuk melepas sepatu agar tidak mengotori lantai dan memanfaatkan fasilitas sekolah sesuai kaidah-kaidah perlindungan dan pengelolaan lingkungan hidup antara lain: 1) pemeliharaan taman; 2) pemeliharaan tanaman obat keluarga; 3 ) pengelolaan hutan sekolah; 4) melakukan pembibitan tanaman ; 5) perawatan kolam; dan 6) pengelolaan sampah. Dalam poin ini yang belum diterapkan adalah tanaman obat keluarga dan pembimbitan dikarenakan pihak sekolah masih berfokus pada pembuatan IPAL untuk mengolah air pembuangan dari kamar mandi, kantin, 
ataupun air wudhu. Sedangkan poin lainnya telah diterapkan melalui Kelompok Kerja Program Adiwiyata Sekolah dengan divisinya masing-masing.

\section{Kegiatan lingkungan berbasis partisipatif yang diterapkan di SMP Negeri 12 Surabaya}

Sekolah memberikan solusi untuk menangani beberapa hambatan dengan membuat program kegiatan. Program kegiatan ini memiliki tujuan untuk menambah pemantapan kualitas sumber daya manusia (SDM) terutama warga sekolah dalam menjalankan kebijakan sekolah peduli dan berbudaya lingkungan. Program kegiatan yang dibuat oleh sekolah ini, tidak hanya untuk mengatasi hambatan tetapi juga merupakan program strategis yang memiliki manfaat untuk program jangka panjang dan berkelanjutan untuk mengemban visi dan misi sekolah peduli terhadap lingkungan (Adam, 2014)

a. Melaksanakan kegiatan perlindungan dan pengelolaan lingkungan hidup yang terencana bagi warga sekolah

SMP Negeri 12 Surabaya memiliki 15 pokja untuk mendukung pelaksanaan program Adiwiyata. Setiap pokja memiliki minimal 2 guru sebagai pembina dan 12 sampai 20 siswa. Pokja tersebut meliputi:

1. Pokja takakura;

2. Pokja komposter;
3. Pokja tong aerob;

4. Pokja pilah sampah;

5. Pokja 4R (reduce, reuse, recycle, replace);

6. Pokja kebun;

7. Pokja toga;

8. Pokja green house;

9. Pokja kantin;

10. Pokja hutan sekolah;

11. Pokja radio;

12. Pokja poling;

13. Pokja IPAL;

14. Pokja jamur;

15. dan Pokja biopori.

Berdasarkan Permen LH No. 5 tahun 2013 tentang pedoman pelaksanaan program Adwiyata, dinyatakan bahwa kegiatan ekstrakulikuler antara lain Pramuka, Karya Ilmiah Remaja, 7 dokter kecil, Palang Merah Remaja, dan Pecinta Alam, yang dimanfaatkan untuk pembelajaran terkait dengan perlindungan dan pengelolaan lingkungan hidup. Menurut pengakuan responden wawancara kami yaitu guru yang bertanggung jawab terhadap Program Sekolah Adiwiyata bentuk perlindungan dan pengelolaan lingkungan hidup tersebut diterapkan dalam hal peserta didik wajib untuk membersihkan dan merapikan tempat dimana peserta didik melakukan aktivitas ekstrakurekuler tersebut. 
Kegiataan lain yang dapat dikatakan sebagai ekstrakurekuler adalah kegiatan Kelompok Kerja Adiwiyata yang memiliki pokok kerjanya masing seperti kebun, komposter, sampah kertas, dan lainlain yang diikuti oleh peserta didik kelas 7 dan 8 serta didampingin oleh 1-2 guru per masing-masing kelompok kerja.

b. Menjalin kemitraan dalam rangka perlindungan pengelolaan lingkungan hidup.

Terkait dengan poin mitra kerja yaitu sekolah wajib menggandeng beberapa mitra yang dimanfaatkan sebagai narasumber untuk meningkatkan pembelajaran lingkungan hidup seperti pelatihan yang terkait perlindungan dan pengelolaan lingkungan hidup, pengadaan sarana ramah lingkungan, pembinaan dalam upaya perlindungan dan pengelolaan lingkungan hidup. SMP Negeri 12 Surabaya telah bekerja dengan banyak mitra diantaranya dengan Tunas Hijau sebagai komunitas yang memberikan materi mengenai pengelolaan lingkungan seperti dalam hal pembuatan pupuk dengan metode takakura, Dinas Kesehatan Kota Surabaya sebagai mitra dalam hal pembinaan kesehatan di lingkungan sekolah seperti pengelolaan Unit Kesehatan Sekolah (UKS) sekaligus menyumbang biopori, UPN, Pelindo III sebagai mitra yang membantu memfasilitasi pembangunan wastafel, dan masih banyak lagi mitra kerja ke depannya yang masih dalam tahap perencanaan.

\section{Pengelolaan sarana pendukung} ramah lingkungan di SMP Negeri 12

\section{Surabaya}

a. Ketersediaan sarana prasarana pendukung yang ramah lingkungan

Sekolah yang menyandang gelar Adiwiyata wajib menyediakan 6 (enam) sarana prasarana untuk mengatasi permasalahan lingkungan hidup di sekolah sesuai dengan standar sarana dan prasarana pada Permendiknas nomor 24 tahun 2007 tentang standar sarana dan prasarana untuk sekolah dasar/madrasah ibtidaiyah (SD/MI); madrasah tsanawiyah,sekolah menengah pertama (MTs/SMP),dan sekolah menengah atas/madrasah aliyah (SMA/MA) seperti : air bersih, sampah (penyediaan tempat sampah terpisah, komposter), tinja, air limbah/drainase, kebisingan/getaran/radiasi, ruang terbuka hijau (RTH) yang mana hal ini belum dapat sepenuhnya dilakukan oleh SMP Negeri 12 Surabaya dikarenakan masih dalam tahap perencaan. Tetapi dalam aspek air bersih, sampah terpisah, ruang terbuka hijau telah diterapkan oleh pihak sekolah dengan maksimal dibuktikan dengan selalu mengalirnya air keran dengan debit yang sudah selayaknya, tersedia tempat sampah
Volume XXI
Nomor 1
Maret 2020

e-ISSN : 2580-9199 
dengan 3 pengkategorian, serta tamantaman sekolah yang rindang.

Sarana prasarana lain yaitu sarana prasarana pendukung pembelajaran lingkungan hidup, antara lain; pengomposan, hutan/ taman/kebun sekolah, kolam ikan, biopori, dan sumur resapan juga telah diterapkan dengan maksimal.

b. Peningkatan kualitas pengelolaan dan pemanfaatan sarana dan prasarana yang ramah lingkungan.

SMP Negeri 12 Surabaya telah memiliki pengaturan cahaya dan ventilasi udara secara alami pada tiap ruangan, pemeliharaan dan pengaturan pohon peneduh dan penghijauan, serta menggunakan paving block pencegah banjir. Kegiatan peningkatan kualitas pengelolaan dan pemanfaatan sarana dan prasarana yang ramah lingkungan tersebut telah diterapkan pula secara maksimal. Kriteria kantin berdasarkan Permen LH No. 5 tahun 2013 tentang pedoman pelaksanaan program Adwiyata yaitu kantin wajib melakukan 3 (tiga) upaya dalam rangka meningkatkan kualitas pelayanan kantin sehat dan ramah lingkungan, meliputi:

a) Kantin tidak menjual makanan/ minuman yang mengandung bahan pengawet/ pengenyal, pewarna, perasa yang tidak sesuai dengan standar kesehatan.

b) Kantin tidak menjual makanan yang tercemar/ terkontaminasi, kadaluarsa.

c) Kantin tidak menjual makanan yang dikemas tidak ramah lingkungan, seperti plastik, styrofoam, dan aluminium foil.

Ketiga upaya ini telah dilakukan oleh pihakkantin SMP Negeri 12 Surabaya dengan tidak ditemukannya bahan pangan pendamping seperti saus tomat, menggunakan piring dan gelas dari kaca yang dapat digunakan kembali, dan setiap kios selalu menjaga kebersihan dan memperhatikan tanggal kadaluarsa dari makanan dan minuman yang dijual.

\section{KESIMPULAN}

SMP Negeri 12 Surabaya merupakan sekolah yang mendapat gelar Sekolah Adiwiyata, dimana sekolah tersebut berhasil dan mampu menerapkan prinsipprinsip lingkungan hidup sesuai dengan Peraturan Menteri Lingkungan Hidup RI Nomor 05 Tahun 2013 tentang pedoman pelaksanaan sekolah Adiwiyata. Hal ini diketahui dengan melihat latar belakang prestasi SMP Negeri 12 Surabaya yang berhasil meraih gelar Adiwiyata Mandiri pada tahun 2019 serta terbukti pada hasilnya keseluruhan aspek yang ada di peraturan tersebut di antaranya kebijakan berwawasan lingkungan, pelaksanaan

\begin{tabular}{|l|l|l|l|}
\hline Volume XXI & Nomor 1 & Maret 2020 & e-ISSN : 2580-9199 \\
\hline
\end{tabular}


kurikulum berbasis lingkungan, kegiatan lingkungan berbasis partisipatif, serta pengelolaan sarana pendukung ramah lingkungan sudah dilaksanakan dengan sangat baik oleh SMP Negeri 12 Surabaya.

Program Sekolah Adiwiyata tidak hanya melibatkan siswa-siswi saja di SMP Negeri 12 Surabaya, namun seluruh warga sekolah tersebut ikut berpartisipasi bahkan orang tua serta pihak luar seperti lembaga swasta maupun pemerintahan juga turut andil dalam bekerjasama mempertahankan status Sekolah Adiwiyata ini.

\section{DAFTAR PUSTAKA}

Adam, A.F.B., 2014. Analisis

Implementasi Kebijakan

Kurikulum Berbasis Lingkungan

Hidup Pada Program Adiwiyata

Mandiri di SDN Dinoyo 2 Malang.

Fakultas Kesehatan Masyarakat

Universitas Indonesia 2, 8.

B. Matthew Miles, H., 1992. Analisis Data Kualitatif.

Hammado Tantu, S., 2016. Pembelajaran Lingkungan Hidup, Cetakan Pertama. ed. Penerbit IPB Press Kampus IPB Taman Kencana, Kota Bogor-Indonesia.

Indra P, B., 2018. Budaya Sekolah Berwawasan Lingkungan Pada Sekolah Adiwiyata Mandiri. Ilmu Pendidikan: Jurnal Kajian Teori dan Praktik Kependidikan 3, 1121.

Laras Sih, S., 2017. Partisipasi Siswa Dalam Pelaksanaan Program Sekolah Adiwiyata Sman 11 Semarang.

Lusty, K.C., 2013. Peran Warga Sekolah dalam Penerapan Pendidikan Lingkungan Hidup di SDN Dinoyo 2 Malang. Malang: Fakultas Ilmu
Pendidikan Universitas Negeri Malang.

Maryani, I., 2016. Evaluasi Pelaksanaan Program Sekolah Adiwiyata Ditinjau dari Aspek Kegiatan Partisipatif di SDN Ungaran I Yogyakarta. JP2SD, 3 1, 170-180.

Peraturan Menteri Lingkungan Hidup Republik Indonesia Nomor 05 Tahun 2013 Tentang Pedoman Pelaksanaan Program Adiwiyata, 2013.

Pradini, I.K., 2018. Implementasi Program Sekolah Adiwiyata dalam Peningkatan Mutu Pendidikan di SDN Tanah Tinggi 3 Kota Tangerang. JGG 7, 122-132.

Suryosubroto, 2009. Proses Belajar Mengajar di Sekolah. Rineka Cipta, Jakarta.

\begin{tabular}{|l|l|l|l|}
\hline Volume XXI & Nomor 1 & Maret 2020 & e-ISSN : 2580-9199 \\
\hline
\end{tabular}

